\title{
REVIEW
}

\section{Imagination in Entrepreneurship: An Inspiration from Heidegger}

\author{
Usman Talat $^{1}$ Kirk Chang ${ }^{2,3 *}$
}

1. Research Fellow and Lecturer, University of Warwick, Coventry CV4 7AL, ENGLAND

2. Salford Business School, University of Salford, The Crescent, Salford, Manchester, M5 4WT, ENGLAND

3. Fudan Development Institute, Think Tank Building, Fudan University, 220 Handan Road, Shanghai, Yangpu District, 200433 CHINA

\section{ARTICLE INFO}

Article history:

Received: 18 December 2018

Accepted: 21 February 2019

Published Online: 30 April 2019

Keywords:

Entrepreneurship

Heidegger

Imagination

Instability

Unpredictability

Spontaneity

\section{ABSTRACT}

Entrepreneur's imagination has crucial implication on business success and management. Despite its espoused importance, imagination is still undervalued and deserves more academic attention. The current article aims to provide a novel perspective on imagination informed by Heidegger (1889-1976; widely acknowledged to be one of the most original philosophers of the 20th century). Specifically, the article has clarified the definition of imagination in entrepreneurship and risen constructs align with the proposed conception. Under the microscope of Heidegger's theory, entrepreneur's imagination co-operates ventures successfully by incorporating notions of webs of significance, authenticity, spontaneity, heroes and moods, which guide opportunity identification and exploration in markets. The article has offered new insights to the knowledge of entrepreneur's imagination. From a pragmatic viewpoint, inferential leaps are possible because entrepreneurs practice against a background of webs of significance they own-which they relationally, linguistically and pragmatically-share across institutional frames. Implications of the findings on management are discussed.

\section{Introduction}

$\mathrm{R}$ ecent studies have shown limited interest in the role of imagination in entrepreneurship. One probable reason is that entrepreneurship is heavily based on theorizing and does not accommodate the inherent instability, spontaneity and unpredictability of imagination. McMullen and Kier ${ }^{[1]}$ argue that despite its espoused importance to entrepreneurial action, imagination is rarely examined and much less defined. In the current article, we align with this argument and provide a perspective on imagination informed by Heidegger (18891976; widely acknowledged to be one of the most original and important philosophers of the 20th century).

This contribution to knowledge acknowledges that in entrepreneurship research there are few scholars who engage directly with the philosophy of imagination to fully theorise about it's nature and role amidst social interactions $^{[2]}$. Historically, traditional equilibrium-based-theories (EBT) of entrepreneurial behaviour have not been concerned with the psychological workings of the imagination. This is surprising because the entrepreneur works to generate new ideas yet the source of these new ideas (i.e. imagination) has received remarkably little attention in research circles ${ }^{[3]}$. A few studies such as Kirzner ${ }^{[4]}$ have

*Corresponding Author:

Kirk Chang

Salford Business School, University of Salford, The Crescent, Salford, Manchester, M5 4WT, ENGLAND

Fudan Development Institute, Think Tank Building, Fudan University, 220 Handan Road, Shanghai, Yangpu District, 200433 CHINA

Email: K.Chang@salford.ac.uk 
advocated the role of imagination as crucial for entrepreneurship. However, for the most part, imagination falls outside the agenda of the EBT approach. In its philosophy the EBT approach, which is a dominant framework in entrepreneurship research, frames organizations as domains "where beliefs converge, products are homogeneous and change is predictable ${ }^{[5] "}$. This type of view is limited because in actual social situations and interactions, beliefs often diverge, the entrepreneur's product is unique and institutional change is difficult to predict. Thus, EBT does not cover what is often the entrepreneur's actual behaviour, which includes using the creative imagination for competitive practices. Instead, it opts in favour of a neoclassical, objectivist and stable view of the entrepreneur's behaviour and markets.

To study the actual process of entrepreneurial behaviour and in response to the objectivist stance of EBT research; the radical subjectivist brand of Austrian economics has emerged to offer a non-equilibrium approach ${ }^{[5,6,7]}$. Whilst studies in this latter approach recognize the potential for investigating the entrepreneurs imagination, thus far, few have ventured in that direction ${ }^{[3,8,9]}$. In conceptual terms the non-equilibrium approach in examining entrepreneurial behaviour, would frame the entrepreneurs imagination as socially constructed, commercially mobilised and a value producing function. That is, studies in this approach tend to adopt a radical subjectivist ontology ${ }^{[5]}$. This means that the entrepreneur's personal episode of imagination represents socially conditioned, co-constructed and negotiated phenomena. In parallel, dividing the space between EBT and the radical non-equilibrium interpretations, the interactionist approach for studying entrepreneurship has also emerged ${ }^{[10]}$. This third approach is concerned with a reality where both personal and contextual factors interact in illustrating and motivating entrepreneurial behaviour such as the imaginative envisioning of opportunity ${ }^{[2,10,11]}$. A similar stance characterizes the critical realist approach found in Schumpeterian economics research on entrepreneurship. However, Schumpeter avoided exploring the entrepreneur's psychology, including the crucial behaviour of imagining creative streaks ${ }^{[5]}$. In the context of the above research approaches, imagination remains an undertheorized construct in the field of entrepreneurship ${ }^{[12]}$. This supports our appetite for new thinking offered in the current article.

We provide a new interpretation of the entrepreneur's imagination employing Heidegger's ideas. Generally, entrepreneurship research has paid limited attention to Heidegger's phenomenological view. Moroz and Hindle ${ }^{[13]}$ recognize Heidegger in advocating the ideas of process philosophy, but do so in a very cursory fashion. Sey- mour ${ }^{[14]}$ provides one of the few explorations of Heidegger's ideas in the context of entrepreneurship; intended to motivate others to ask foundational questions including "How are opportunities perceived and recognized by others?" In this regard, we contend that underpinning entrepreneurial theorizing or rationality about market conditions and discovery of opportunities (i.e. the radically new or unique) lies the synthetic power of imagination.

\section{Literature Review}

\subsection{About Entrepreneur's Imagination?}

Heidegger ${ }^{[15]}$ investigated Kant's Critique of Pure Reason and he argued that with regard to imagination Kant's understanding had to be reversed. In volume one of the critique, Kant concluded that imagination in its productive power is the fundamental human capacity that makes all phenomenological synthesis possible to account for our knowledge and experiences in society. Subsequently, in volume 2, Kant changed his mind, and now argued that imagination is a function of the understanding ${ }^{[16]}$. Heidegger $^{[15]}$ argues that Kant's interpretation of volume one applies more satisfactorily in explaining the power of human imagination. That is, the entrepreneur, at a fundamental cognitive level - at the root of the mind - utilizes the productive power of the imagination for reasoning and desire in living life. This idea is also suggested in economic thought regarding entrepreneurs. Penrose ${ }^{[17]}$ saw imagination as a fundamental productive capacity for enterprising activity. Compared to Schmumpeter who took the entrepreneur from the viewpoint of the economy as a whole, Penrose focused on the firm level development of the entrepreneur as innovator. In Heidegger's thought, the individual entrepreneur can know something at a base level because the primordial synthesizing capacity of imagination integrates self-consciousness and knowledge of the world - this is "the transcendental power of imagination, which makes all synthesis possible ${ }^{[16]}$. Entrepreneurship research has dedicated limited attention to this argument about imagination as a fundamental productive and synthesizing force driving behaviour.

In what is often recognized as his magnum opus titled, Being and Time, Heidegger further develops a picture of social reality and its markets; we contend in the current article that it is here that a new conception of how the entrepreneur imagines creative endeavors is available. More specifically, for Heidegger we live everyday life not by imagining ourselves as subjects surrounded by distinct objects ${ }^{[18]}$. We live everyday life by tending to practical affairs through tools that are ready to hand ${ }^{[14]}$. That is, they are there, available to us (like the tools on your office desk, car keys, keyboard, pencils and paper, 
your keys). Commonly, these tools are applied without reflective thought, and thus act as extensions of the entrepreneur; rather than as separate reflected upon entities ${ }^{[19]}$. As remarked by Goldie ${ }^{[20]}$ we exist in the swim of life as we navigate, feel and act ourselves. In actual practicalities of markets, we do not hold the world up for theoretical investigation like a philosopher or reflective actor might do. We instead are the there, what Heidegger calls Dasein.

From this viewpoint, Heidegger contends that the Cartesian duality is a propositional framework introduced later by reflective thinking of philosophers and academics; here what is more fundamental is our everyday dwelling in the world. We live life immersed in the world, without necessarily examining it in a propositional sense until something occurs to breakdown our routines and disturb our practices. Chia and Holt ${ }^{[21]}$ propose that in organizations we dwell and act everyday to give rise to entrepreneurial strategies, and that this often happens without conscious deliberation. That is, consistent and useful practices often emerge through a culturally mediated modes operandi (i.e. everyday habits of work). At the same time, Heidegger does not offer a picture of the entrepreneur as entirely automaton like. He argues that we do create meaning and solutions to problems when our workings in the world breakdown; that is, when our pathways face difficulties. Consider that when our habitual practices face challenges during organizational change or market upheavals, we set out to create solutions so we may continue our path forward. Crucially this suggests that in the behaviour of successful entrepreneurs imaginative powers shape perspectives that extend beyond those pathways that are already given as operationally, ritualistically, normatively and institutionally available. This thought has been raised by Martin ${ }^{[22]}$ who argues that imagination surpasses institutional routines and patterns of social behaviour that reflect inductive and deductive institutionalized logics.

As a synthetic force that underlines reason, desires and our agency; for Heidegger imagination is about higher cognitive power to create new meaning and hence pathways forward. For instance, in a study by Mueller et $\mathrm{al}^{[23]}$ it was concluded that everday tasks of entrepreneurs in the start-up and growth-stage include - delegation, engineering tasks, and business administration actions. Crucially, additional tasks of the entrepreneur include conversations, opinion generation and managing self and others. Heidegger points out that these latter complex and meaningful tasks, as well as the former more habitual modes of practically coping in the workplace, constitute the maintenance of a social habitat that entrepreneurs are in the swim of and care about in manifold ways ${ }^{[18]}$. Therefore, in addition to dwelling unreflectively, we also move about with a de- gree of reflection in pursuit of entrepreneurial goals. But in Heidegger's thought the entrepreneur's imagination is not free and nor without socio-historical backdrop.

He argued that in reflecting - propositionally or imaginatively - the entrepreneur cannot just willfully find opportunities and solve challenges. Rather, he is thrown in a situation where he operates with care or concern through tools that are extensions of himself ${ }^{[14]}$. This notion of thrownness means that there are things entrepreneurs are driven by and can do little to change. We find ourselves thrown into institutional sites of interaction and relations that are somewhat given to us ${ }^{[24]}$. For example, take the millennial entrepreneur who is born in a certain culture, a certain time in history, perhaps the digital era of Steve Jobs or Mark Zuckerberg. He or she has a certain place in society and is provided a certain language and existence. In other words, thrownness means that the past defines the possibilities open to that entrepreneur in any given situation. In probing organizational relations and terrain for opportunity, the entrepreneur in the present is always ahead of himself; always leaping towards goals and imagined possibilities; as potentialities ${ }^{[25,26]}$. Thus, at any institutional site, the dwelling entrepreneur is limited by being thrown into sites of institutional and social conditions and practices, but he also works to shape future pathways through the imagination. One lives ahead of himself by anticipating possible futures (i.e. building mode).

In the Heideggerrean framework, this presents imagination as creative in its power. Crucially, imagination is associated here with what Heidegger calls occurrentness. We introduced this earlier as a mode of engaging challenges we face when our pathways and life projects breakdown; which propel us to build new possible futures or solutions by creatively imagining things - the building mode. Imagination of the entrepreneur here manifests at the boundary between what works and goes unnoticed; and what occurs as malfunctioning, as obstrusive and thus identified as an issue one needs to deal with through mental machinery.

We contend that both the first mode of dwelling in markets and the secondary mode of occurrentness and building solutions to problems encountered; represent a back and forth terrain of entrepreneurial behaviour where imagination manifests. Whilst, Chia and Holt ${ }^{[21]}$ have acknowledged the deployment of inductive and deductive reasoning on this terrain, we extend this view by introducing imagination as a necessary capacity for creative endeavors of entrepreneurs.

\subsection{Alternative Thought of Imagination}

For management and entrepreneurship researchers the imagination is useful because it can be perceived as re- 
sourceful and a source of advantage $\mathrm{e}^{[2]}$. More generally, a key indicator of any organizational resource has been the extent to which it is manageable for development and commercial appropriation. Over the course of the last 100 years, out of the psychological capacities of the organizational actor and entrepreneur, reason has reigned supreme as amenable with and supportive of, normative institutional frameworks ${ }^{[27]}$. This represents the individual as possessing serial processing capacities. In Heidegger we find a different perspective. He agreed with Kant's interpretation that imagination is more fundamental then reason ${ }^{[16]}$. Compared with our capacity to reason, this presented imagination as a force underlying entrepreneurial behaviour. Although Heidegger did ascribe immense importance to reason in the development of the sciences, imagination remained the more holistic capacity perineal across social circles.

Within the broader Heideggerrean framework of Being and time; we suggest that imagination takes on a more complete and holistic picture. For instance, consider that in dwelling about markets, the entrepreneur lives at times by ascribing meaning through personal webs of significance. These webs unfold in organizational sites where the temporal structure of care operates as being-there "Dasein" with a given past, engrossing present and anticipatory future. That is, thrown into an organizational site or situation, against a background of what is given, the entrepreneur has fallen into present social frameworks, is always ahead of himself, either dwelling so, or actively building some imagined solution to occurred problems. Secondly, in Heidegger's thought, behavior at organizational sites is not to be understood in terms of some mind-matter duality. Instead, it involves the meshing of narratives and images in a personal web of significance that is ever-present in the backdrop to each action. As pointed out by Seymour ${ }^{[14]}$ who argues that entrepreneurship can benefit from a Heideggerean conception, "Our fundamental sense of things is not as objects of perception and knowledge, but as instruments/equipment that fit naturally into our ordinary everyday practical activities".

Inwood (2000:35) expounds Heidegger's notion of a web of significance in the following passage where he presents it as unobtrusive and tacitly present to everyday coping activities of a craftsman. "The craftsman....... when he is engrossed in hammering a nail, does not explicitly notice or attend to the bench he is working on, the stool he sits on, the supply nails beside him.....These things are there for him, he is tacitly aware of them.....these entities refer to each other and constitute a web of significance". The individuals web of significance provides what Dreyfus ${ }^{[28]}$ calls the background to everyday coping activities of individual actors. We contend that the individual enters the entrepreneurial mode of perceiving opportunity when the taken-for-granted parts of this web of significance are questioned. As Inwood ${ }^{[2]}$ points out, this happens when there is a breakdown in the working order of things. This is where the entrepreneur arrives on the scene to fix the malfunctioning joints of market reality. This is where institutionally established and inferentially programmed pathways have broken down. That is, where problems occur in given regularities; we find the emergence of entrepreneurial modes of coping to solve issues by creatively imagining opportunities. It is important to note that the web of significance avoids the subject-object divide. We feel this should be emphasized in entrepreneurship studies. Chia and Holt's ${ }^{[21]}$ reading of Heidegger in explaining 'organizational behaviour perhaps inadvertently misleads readers in this respect. For instance, they acknowledge "individual engagement" as well as "structuring forces of such engagement" and in this sense implicate a subject-object divide. This should be avoided if Heidegger's thought is to inform entrepreneurship research. In the process of questioning the taken-for-granted parts of one's web of significance at a given organizational site, what we call "pockets of opportunity", tend to emerge.

For example, consider the case of the Chinese conglomerate Alibaba. During the early 90s the entrepreneur Jack Ma, realised that Chinese business was conducted against a backdrop of already laid out ready-to-hand tactics that were meaningful within the context of the larger web of significant Chinese institutions, practices, rituals, norms and habitus ${ }^{[18]}$. He identified the taken-for-granted parts of this web and expanded them into a bigger context. He questioned Chinese commerce not within China, but within the larger web of country level dynamics occurring internationally. In effect, Jack Ma, rather than operating within already laid out logics, expounded to superordinate categories that normally go unquestioned as part of the background to social behaviour ${ }^{[14][28]}$. He sought to reform market realities by introducing electronic technology at its joints to provide new opportunity. This enabled him to imagine during the early nineties that "what-If" electronic technology (namely, the internet) were to be used to do Chinese business. His imagination set Chinese business free from the local past and tradition, and towards a more global historical appreciation beyond just his lifetime.

This example demonstrates that an individual within their web of significance, within their carefully carved out history and social context that is given to them; can use the synthetic power of imagination to reconfigure inferential pathways that have previously been take for granted as background institutionalised frames of reference. The 
pocket of opportunity (i.e. potential integration of new technology) in this example is one that is brought to the fore from the background of everyday coping activity, through the power of enterprising imagination. How one is enabled is to rise above markets by abstract power of imagining - indeed this addresses the question "How can actors change institutions if their actions, intentions, and rationality are all conditioned by the very institutions they wish to change" ${ }^{[30]}$. We contend that alternative realities of imagining are pathways available for creative change, over and above already laid out institutional logics.

\subsection{Representational Spontaneity and Authenticity}

For Heidegger "time" is a fundamental category. The entrepreneur's experience of time is an organization of meaning against a background - web of significance. This suggests for instance that the time spent on a problem is not experienced in terms of discrete units objectively measurable and theoretically thought out and embodied in vulgar clocks that reflect organized thinking. Instead, social actors live time in projecting the self into action in reckoning with the world; they imagine towards possibilities - this is what Bakken et al ${ }^{[26]}$ call "world time". In this heidegerrean conception, we identify representational spontaneity as a crucial property of the entrepreneur's imagination required for opportunity identification and exploration.

Specifically, by representational spontaneity we mean systemized cognitive processes that abruptly and creatively perturb the world time experience of entrepreneurial social actors. These processes underline the entrepreneur's experience of spontaneously generating vivid images to creatively theorize. That is, to reorient through mental representation, that which is in front of your nose. Specifically, this is a radical re-conceiving away from the otherwise "mass society of blind conformity" ${ }^{[31]}$. This is crucial for opportunity identification and exploration, which often involves reading between the lines. Sartre ${ }^{[32]}$ who was influenced by Heidegger, saw spontaneous image representation of experience, as a powerful way of changing the course taken by social actors living in the world with each other, always leaping into the future, amidst world time.

But this spontaneous generation and representation of the 'now experience' is based on a deeper argument by Heidegger. He suggests that the individual who is able to look beyond the past and future of one's own life by being $\mathrm{i} /$ free of the falleness of the present and ii/by reaching beyond just one's life-span, will creatively use the power of the imagination to reorient current institutional frames. A person who does this is authentic in the Heideggerean sense. One has escaped the inauthenticity of the they, the social, that one had fallen into, and thereby is set free to reconsider a bigger picture from a more authentic or we might say 'outside the box' view of market dynamics.

This suggests that highly entrepreneurial individuals operate outside their immediate world time constraints. For example, during the 1980's entrepreneurs like Bill Gates and Steve Jobs, could chase specific technologies in the context of their factual possibilities and beyond towards greater significance and historicity - free from nature, society, biology and economy. These entrepreneurs sought radical action ${ }^{[31,33]}$. They were free to imagine radical new possibilities because they had moments of standing outside all societal significations, immediate epochs and market constraints ${ }^{[34]}$. That is, they used the power of imagination to think in an authentic mode and to see opportunities that otherwise remain hidden for those entrepreneurs that remain fallen in the present encompassing limits of market and social frameworks and prescriptions.

\subsection{Death, Heroes and Moods}

For Heidegger the enterprising individual, who seeks novel resolve to projects and issues in markets, will find authenticity when he breaks free of them (i.e. the social mass) in the context of being aware of the inevitable end: his death.

Crucially, to find that novel possibility for resolve, when looking across available possibilities in the face of death, the individual repetitively returns to the past, perhaps his own past, or more likely even further to interpret imagined others of another era. The enterprising individual will "choose its hero" ${ }^{[35]}$. The creative entrepreneur looks at suggestions made by deeds of past heroes who he brings to life in the anticipatory frameworks of projected possibilities, thereby, disavowing what is offered by them (i.e. society) of the now. In this respect Inwood ${ }^{[29]}$ points out that most individuals fallen into what is prescribed and what dominates them as social structures, circles and markets "..opt for roles one of the roles handed down from the immediate past - the shoemaker, a priest, a sexton" and so on. The implication of this is described by Seymour ${ }^{[14]}$ who states that: "We are continually absorbed in the entities presently encountered and are entangled in (or have fallen prey to) the present. This entanglement means that we do not challenge the conventions of the world and do not make clear choices."

In this context, one may propose that creative entrepreneurs-unlike most people-can become alert to new reference points in the now by reaching in repetition to past heroes beyond their own birth, and having conversations with those of another era. This process of breaking free from social constraints of the them that seek to absorb 
individuals into inauthenticity can free the entrepreneur to play out his own imagined derivatives of heroism in the here, where one continually projects. Crucially, this care for past, present and future possibility of possibilities never stops. For individuals including highly enterprising ones are continually in process ${ }^{[36]}$. In his book The Denial of Death Becker ${ }^{[37]}$ tells us that "We are living a crisis of heroism that reaches into every aspect of our social life". In effect, without heroes society and the entrepreneur would fall into mediocrity and the social mass of homogeneity.

An important concept in Heidegger's philosophy that applies to entrepreneurial behaviour, specifically imagination, is the notion of moods. In organizational behavior and management research, the term mood is often used interchangeably with emotion ${ }^{[38]}$. The study by Seymour ${ }^{[14]}$ that emphasizes the primacy of entrepreneurial moods from a Heideggerrean perspective, perhaps inadvertently so; uses the example of fear, which is an emotion and not a mood. Thus, in exploring how moods may guide entrepreneurial imagination one must distinguish it from an emotion. Whilst emotions are directed, intentional and about specific things - such as anger at organizational change - by contrast the entrepreneur's mood is a relatively non-intentional existence of a more generic disposition. Whilst emotions are object specific, moods are more global. One may be in a mood of unease or angst without knowing particular causes. These disclose the unobtrusive pre-theorized understanding of the world ${ }^{[29]}$.

Therefore, Heidegger argues that we dwell in the world and then we build things such as houses and offices, social rituals, and mental interpretations of things. "Only if we are capable of dwelling, only then can we build ${ }^{[39]}$. However, preceding the reasoning and theorizing explicable in building the world, the entrepreneurs dwells at a fundamental level through moods ${ }^{[36]}$. These moods reveal a deeper connection and aspect of our world, laying it bare. Imagination in this context provides mental images as points of integration between a mood and some more explicit rationale or theorizing of what one finds in existing from one moment to the next. The power of images as integrative is explained by Cornellissen ${ }^{[40]}$, who writes, that in the entrepreneurs worldview:

"A vision in my mind, essentially blends or fuses different sets of ideas into a single guiding image, which, in turn, may trigger all sorts of inferential leaps".

The entrepreneur's imagination is a fundamental synthetic power in Heidegger that is essential for any human being in the world experiencing it by dwelling across markets. It is pre-theoretical, pre-rational ${ }^{[36]}$ - imagination here configures into how entrepreneurs may question markets and social mechanisms- by framing (i.e. questioning) a problem or issue. Thus, imagination in Heidegger's philosophy underpins reason and practice, it provides an anticipatory reality ${ }^{[41]}$; but it is also contingent with the construction of reasoned, practical and affective organizing of social systems such as capitalism and market dynamics. We recognise that imagination 'primordial to' but also 'necessary for' what Tsoukas ${ }^{[42]}$ describes as thematic awareness which emerges parallel to practical coping modes of beings. For instance, the entrepreneur may be engaged in developing organizational design in abstracto, whilst at other times he may practically be living and coping through that design everyday, as unobtrusive background webs of significance. Here, imagination bridges abstract category formation and unreflected practice in dwelling across markets.

\section{Discussion and Conclusion}

Our review suggests that a conception based on Heidegger's philosophy which emphasizes the entrepreneur as perpetually projecting possibilities for markets, is uniquely suited for research into how imagined and novel outcomes are practiced through entrepreneurial behavior. We have proposed specific constructs and argued for their place in theory as well as implications (Table 1).

We have discussed examples to show why Heidegger's thought have explanatory power for practice. Philosophically, in seeing the world without a Cartesian framework, Heidegger provides a perspective much closer to how entrepreneurs actually go about in their markets, acting and doing things, rather than theorizing most of the time like a scientist or researcher might $\mathrm{do}^{[18,36]}$. In a sense, this has also led to the realization that entrepreneurs live in a reality far from linear and much more complex under the notion of time in Heidegger's thought ${ }^{[43]}$. From a pragmatic viewpoint we find that cognitively speaking, inferential leaps are possible because entrepreneurs practice against a background of webs of significance they own-which they relationally, linguistically and pragmatically-share across institutional frames. We propose creative entrepreneurs question these webs. For example, Starbucks was discovered because Howard Schultz questioned the culturally taken for granted parts of coffee shops in Italy. He dared to replace the background to action and meaning found in Seattle and across the world with what he found in Italian culture ${ }^{[44]}$. Rather than being stuck in already laid out institutional logics-he imagined new possibilities. Similarly, "Uber applied its successful driver model to meals and created UberEats"-this involved questioning taken-for-granted parts of the background to how business is normally done $\mathrm{e}^{[45]}$. 
Table 1. Knowledge Advancement in Entrepreneurship

\begin{tabular}{|c|c|c|}
\hline Construct & Argument & Implication \\
\hline Non-Cartesian & $\begin{array}{l}\text { We argue that Heidegger's theory grounded in every- } \\
\text { day relationality }{ }^{[49,21]} \text { emphasizes thinking of entrepre- } \\
\text { neurial imagination as beyond the mind-body split. }\end{array}$ & $\begin{array}{l}\text { This provides a pre-theorized grounded plat- } \\
\text { form to study behavior }{ }^{[14]} \text {. The entrepreneur } \\
\text { usually acts and imagines without holding the } \\
\text { market up as duality between "I" and "other". }\end{array}$ \\
\hline $\begin{array}{l}\text { Dwelling, Occurrentness } \\
\text { and Building mode }\end{array}$ & $\begin{array}{l}\text { Chia and Holt }{ }^{[2]]} \text { recognize dwelling and building as } \\
\text { modes in the strategy-as-practice school }{ }^{[48]} \text {. We argue } \\
\text { that beyond deductive and inductive reasoning; imagi- } \\
\text { nation is necessary for creative endeavors. }\end{array}$ & $\begin{array}{l}\text { These concepts expose imagination as a capac- } \\
\text { ity that synthesizes through images that which } \\
\text { inductive and deductive reasoning alone can- } \\
\text { not enable entrepreneurs to do. Cornellisen }{ }^{[40]} \\
\text { and Martin }{ }^{[22]} \text { to an extent have proposed this } \\
\text { idea. We place it within Heidegger's thought } \\
\text { applied to entrepreneurs. }\end{array}$ \\
\hline Webs of Significance & $\begin{array}{l}\text { We contend that across markets and institutions, } \\
\text { the entrepreneur perceives opportunity when tak- } \\
\text { en-for-granted parts of one's web of significance are } \\
\text { questioned. Whilst inferentially set pathways, institu- } \\
\text { tional logics, and social regularities of practice break- } \\
\text { down and demand re-cognition }{ }^{[21]} \text {, it is here that we } \\
\text { argue the entrepreneurs imagination provides creative } \\
\text { re-shuffling of reality. }\end{array}$ & $\begin{array}{l}\text { In essence, imagination in Heidegger's thought } \\
\text { creates new institutional logics by rising above } \\
\text { constraints of everyday accepted norms. To an } \\
\text { extent, it sets individuals free of the they (i.e. } \\
\text { consuming social mass); towards a mode of } \\
\text { questioning taken-for-granted parts of what } \\
\text { Dreyfus }{ }^{[28]} \text { calls the background to everyday } \\
\text { action. }\end{array}$ \\
\hline $\begin{array}{l}\text { Authenticity and Repre- } \\
\text { sentational spontaneity }\end{array}$ & $\begin{array}{l}\text { The entrepreneur who provides creative resolve breaks } \\
\text { away from the they (the social mass) into which in- } \\
\text { dividuals have fallen to conform to social identities, } \\
\text { rules and norms }{ }^{[31]} \text {. We propose based on Heidegger } \\
\text { and his contemporary Sartre }{ }^{[32]} \text { that images one imag- } \\
\text { ines are spontaneous representations }{ }^{[50]} \text {. These can } \\
\text { enable the entrepreneur to be partially authentic and to } \\
\text { stand outside institutional frames to reconfigure them. }\end{array}$ & $\begin{array}{l}\text { In the field of entrepreneurship our proposal } \\
\text { that entrepreneurs garner creative resolve } \\
\text { through authenticity, provides a new construct. } \\
\text { Bakken et } \mathrm{a}^{[26]} \text { recognize that those seeking a } \\
\text { new path (heroes and knights) in the finitude } \\
\text { of life seek authentic practices. We identify } \\
\text { the entrepreneur as a knight of the markets; a } \\
\text { trendsetter and adventurer. }\end{array}$ \\
\hline Death, Heroes and Moods & $\begin{array}{l}\text { Heidegger presents death as the possibility to end all } \\
\text { possibilities of life. In the face of death, the entrepre- } \\
\text { neur looks to heroes. He seeks new reference points in } \\
\text { the now by reaching in repetition to past heroes beyond } \\
\text { his own birth, and having conversations with those of } \\
\text { another era }{ }^{[29]} \text {. In generating derivatives of heroics, the } \\
\text { entrepreneur may live beyond life by perceiving and } \\
\text { practicing creative products to mythologize the self; to } \\
\text { provide societal ideals and direction Godelier }{ }^{[51]} \text { and } \\
\text { Ganzin et al }{ }^{[46]} \text { lean towards this idea. We also argue that } \\
\text { moods of entrepreneurs and more explicit theorizing are } \\
\text { notions bridged by images that integrate ideas playfully. }\end{array}$ & $\begin{array}{l}\text { Bakken et } \mathrm{al}^{[26]} \text { who draw on Heidegger to dis- } \\
\text { cuss the construct of world time, have explored } \\
\text { the notion of death. But limited attention is } \\
\text { given to it in the field. For entrepreneurship, } \\
\text { we place death alongside Heroism and moods, } \\
\text { to provide a new perspective on imagination. } \\
\text { This is one that has not been explored before. } \\
\text { However, it builds on the call for greater } \\
\text { research on entrepreneurship from a Heideg- } \\
\text { gerean perspective }{ }^{[14]} \text {. }\end{array}$ \\
\hline
\end{tabular}

The notion of heroes that we have proposed from a Heideggerean perspective is also found in practice. For example, the mythologizing of Jack Welch and Steve Jobs continues to symbolize a heroism-an attractive image-for those seeking innovations that immortalize the self in the face of death. These are motivations to create by imagining beyond both one's birth and death. New meaning and invention can come from reaching beyond limits of one's generation and bringing home what is authentic and outside one's current epoch. In this regard, organizations often construct narratives to mythologize entrepreneurs and leaders ${ }^{[46]}$. These narratives motivate social perceivers to look beyond self-interests and towards more global concerns, which Heidegger argues are revealed through the attunement of their moods.

Another construct that influences our understanding 
of entrepreneurial practice is the notion of moods proposed in Heidegger's thought ${ }^{[14,29]}$. Whilst the notion of emotional intelligence has been extensively applied to practice including the development of measures such as the emotional quotient ${ }^{[47]}$; by comparison the construct of mood is a lower level relatively global feeling. Moods are comparatively low level and long lasting, they provide what Heidegger has described as tuning into existence. We argue that moods and reasoning are integrated or bridged through images of the entrepreneur. For practice, this means that imagination enables creative re-shuffling of market realities.

\section{References}

[ 1 ] McMullen, J. S., \& Kier, A. S. (2017). You don't have to be an entrepreneur to be entrepreneurial: The unique role of imaginativeness in new venture ideation. Business Horizons, 60(4), 455-462.

[2] Thompson, N. A. (2018). Imagination and creativity in organizations. Organization Studies, 39 (2-3), 229-250.

[ 3 ] Kier, A., \& McMullen, J. S. (2018). Entrepreneurial Imaginativeness Within New Venture Teams: A Key to Startup Performance. In Academy of Management Proceedings (Vol. 2018, No. 1, p. 10474). Briarcliff Manor, NY 10510: Academy of Management.

[ 4 ] Kirzner, S.M. (1999). Creativity and/or alertness: A reconsideration of the Schumpeterian Entrepreneur. Review of Austrian Economics, 11: 5-17.

[ 5 ] Chiles, T.H., Vultee, D.M., Gupta, V.K., Greening, D.W., \& Tuggle, C.S. (2010). The philosophical foundations of a radical Austrian approach to entrepreneurship. Journal of Management Inquiry, 19 (2): 138-164.

[6] Foss, N. J., \& Ishikawa, I. (2007). Towards a dynamic resource-based view: Insights from Austrian capital and entrepreneurship theory. Organization Studies, 28(5), 749772 .

[ 7 ] Kirzner, I. (1973) Competition and entrepreneurship. Chicago: University of Chicago Press.

[ 8 ] Miller, D., \& Breton-Miller, I. L. (2017). Underdog Entrepreneurs: A Model of Challenge-Based Entrepreneurship. Entrepreneurship Theory and Practice, 41(1), 7-17. https://doi.org/10.1111/etap.12253

[9] Shalley, C. E., \& Perry-Smith, J. E. (2001) Effects of socialpsychological factors on creative performance: The role of informational and controlling expected evaluation and modeling experience. Organizational Behavior and Human Decision Processes, 84: 1-22.

[10] Zhou, J. (2008) Promoting creativity through feedback. In J. Zhou \& C. E. Shalley (Eds.), Handbook of organizational creativity: 125-145. Hillsdale, NJ: Lawrence Erlbaum.

[11] Shalley, C. E., Zhou, J., \& Oldham, G. R. (2004) The effects of personal and contextual characteristics on creativity: Where should we go from here? Journal of Management, 30: 933-958.

[12] Soares Traquina Alves Elias, S. R., \& Chiles, T. H. (2017). Creative imagining: Developing and grounding a process model for entrepreneurship. In Academy of Management Proceedings (Vol. 2017, No. 1, p. 12191). Briarcliff Manor, NY 10510: Academy of Management

[13] Moroz, P. W., \& Hindle, K. (2012). Entrepreneurship as a process: Toward harmonizing multiple perspectives. Entrepreneurship Theory and Practice, 36(4), 781-818.

[14] Seymour, R. G. (2006). Hermeneutic phenomenology and international entrepreneurship research. Journal of International Entrepreneurship, 4(4), 137-155

[15] Heidegger, M (1997) Kant and the Problem of Metaphysics. 5th edition Translated by R.Taft. USA: Indiana University Press.

[16] Harding, A. J. (1996). Imagination, Patriarchy, and Evil in Coleridge and Heidegger. Studies in Romanticism, 3-26.

[17] Penrose, E. T. (1980) The Theory of the Growth of the Firm. Oxford: Blackwell

[18] Holt, R., \& Mueller, F. (2011). Wittgenstein, Heidegger and drawing lines in organization studies. Organization Studies,32(1), 67-84.

[19] Tsoukas, H. (2005). Complex knowledge: Studies in organizational epistemology. Oxford: Oxford University Press.

[20] Goldie, P. (2004). Emotion, Feeling, and Knowledge of the World. In Thinking About Feeling: Contemporary Philosophers on Emotions, (Ed) R.C.Solomon, 91-106. New York: Oxford University Press.

[21] Chia, R., \& Holt, R. (2006). Strategy as practical coping: A Heideggerian perspective. Organization studies, 27(5), 635-655.

[22] Martin, R. (2010), "Management by imagination", Harvard Business Review, pp. 64-65.

[23] Mueller, S., Volery, T., \& Von Siemens, B. (2012). What Do Entrepreneurs Actually Do? An Observational Study of Entrepreneurs' Everyday Behavior in the Start $\square \mathrm{Up}$ and Growth Stages. Entrepreneurship Theory and Practice, 36(5), 995-1017.

[24] Hernes, T., Simpson, B., \& Soderlund, J. (2013). Managing and temporality. Scandinavian Journal of Management, 29(1), 1-6.

[25] Horrigan-Kelly, M., Millar, M., \& Dowling, M. (2016). Understanding the key tenets of Heidegger's philosophy for interpretive phenomenological research. International Journal of Qualitative Methods, 15(1), 1609406916680634

[26] Bakken, T., Holt, R., \& Zundel, M. (2013). Time and play in management practice: An investigation through the philosophies of McTaggart and Heidegger. Scandinavian 
Journal of Management, 29(1), 13-22.

[27] Bruton, G. D., Ahlstrom, D., \& Li, H. L. (2010). Institutional theory and entrepreneurship: where are we now and where do we need to move in the future?. Entrepreneurship theory and practice, 34(3), 421-440.

[28] Dreyfus, H. L. (1981:66). From micro-worlds to knowledge representation: AI at an impasse. Mind design, 161204.

[29] Inwood, M. J. (2000). Heidegger: A very short introduction(Vol. 25). Oxford Paperbacks.

[30] Holm, P. (1995:398). The dynamics of institutionalization: Transformation processes in Norwegian fisheries. Administrative science quarterly, 398-422.

[31] Wolin, R. (2001). The Hannah Arendt Situation. New England Review (1990-), 22(2), 97-125.

[32] Sartre, J. P. (2013). The psychology of the imagination. London:Routledge.

[33] Marcuse, H. (2005). Heideggerian marxism. University of Nebraska Press: Nebraska.

[34] Farin, I. (2013). Three levels of historical analysis in early Heidegger. The New Yearbook for Phenomenology and Phenomenological Philosophy XII, (XII), 1-37.

[35] Heidegger, M (1962) Being and Time. Oxford:Blackwell

[36] Nayak, A., \& Chia, R. (2011). Thinking becoming and emergence: process philosophy and organization studies. InPhilosophy and organization theory (pp. 281-309). Emerald Group Publishing Limited.

[37] Becker, E (2018) The Denial of Death. London: Souvenir Press Limited.

[38] Gooty, J., Gavin, M., \& Ashkanasy, N. M. (2009). Emotions research in OB: The challenges that lie ahead. Journal of Organizational Behavior: The International Journal of Industrial, Occupational and Organizational Psychology and Behavior, 30(6), 833-838.

[39] Heidegger, M. (1971). Poetry, language, thought. New York: Harper \& Row.
[40] Cornelissen, J. P. (2013). Portrait of an entrepreneur: Vincent van Gogh, Steve Jobs, and the entrepreneurial imagination.

[41] O'Connor, K. P., \& Aardema, F. (2005). The imagination: Cognitive, pre-cognitive, and meta-cognitive aspects.Consciousness and Cognition, 14(2), 233-256.

[42] Tsoukas, H. (2010). Practice, strategy making and intentionality: a Heideggerian onto-epistemology for strategy as practice. Cambridge handbook of strategy as practice, 47-62.

[43] Dodd, S. D., Anderson, A., \& Jack, S. (2013). Being in time and the family owned firm. Scandinavian Journal of Management, 29(1), 35-47.

[44] Keller, K. L. (2000). The brand report card. Harvard Business Review, 78(1), 147-158.

[45] Young, K. (2018), "The Simple Question That Can Make or Break a Startup". Boston: Harvard Business Review.

[46] Ganzin, M., \& Gephart Jr, R. P. and Suddaby, R. (2014) Language and Communication at Work: Discourse, Narrativity, and Organizing, 4, 219.

[47] Mayer, J. D., Caruso, D. R., \& Salovey, P. (2016). The ability model of emotional intelligence: Principles and updates. Emotion Review, 8(4), 290-300.

[48] Anderson, A. R., Dodd, S. D., \& Jack, S. (2010). Network practices and entrepreneurial growth. Scandinavian Journal of Management, 26(2), 121-133.

[49] Jack, S., Dodd, S. D., \& Anderson, A. R. (2008). Change and the development of entrepreneurial networks over time: a processual perspective. Entrepreneurship and Regional Development, 20(2), 125-159.

[50] Talat, U., \& Chang, K. (2017). Employee imagination and implications for entrepreneurs: Inspiration from Chinese business enterprises. Journal of Chinese Human Resource Management, 8(2), 129-152.

[51] Godelier, E. (2010). Myths of the Entrepreneurial Elite. Historical Reflections/Réflexions Historiques, 36(3), 75-93. 